A publication of the Muma College of Business | University of South Florida

\title{
KEEPING COLLEGE EMPLOYEES AMID COVID-19 ${ }^{1}$
}

\author{
How to keep your employees when you don't know how a pandemic will impact your bottom line?
}

It wasn't just any other sleepless night for Tonjua Williams, president at St. Petersburg College. She lay awake thinking of the consequences over and over in her mind with the growing pressure of closing the college where she had worked for over 33 years. Up against the anticipation of the Governor's order to stay at home amid the COVID-19 pandemic, and what was in the best interest of students and employees, it wasn't the decision to close the college and go online that was difficult. The toughest decision was how to keep her employees employed with unknown resources.

By March 2020, Dr. Williams had been president at SPC for just under three years, its seventh president in nearly 100 years, and first female and African American leader. She had been the beacon of hope for communities of people who yearned to rise from poverty to prosperity. Afterall, Williams had accomplished that herself.

Soon after becoming president, Dr. Williams focused on a new way of operations, through a Community of Care. The internal community was of utmost importance because the college family fueled the institution and the success of its students. The Community of Care ensured that the college's people felt wanted, appreciated, valued, regarded, and respected. This was especially important for the employees and students who lived in poverty and were striving to improve their lives and the lives of their families. Dr. Williams realized that there were many like her at the college who knew first-hand what it was like to be raised in poverty but had the potential to achieve economic success.

So, it was no surprise that one of Dr. Williams' strongest commitments during this time was to maintain employment for all. "I get up every morning to figure out what I can do to make life better for someone else, because someone did that for me," she has said. In all the hard times she experienced as a child, it was her mother that said, "We'll get through this." It was her chance to say the same to her employees. But she knew if she were faced with a significant budget cut, it would most likely come from personnel. Employees represented $80 \%$ of the college's operating expenses.

Dr. Williams found herself contemplating options. Budget considerations were top of mind, with volatile enrollment and unknown state funding amounts for the upcoming fiscal year. Does she furlough everyone? Does she lay off people? Does she keep everyone on board, but implement pay cuts? She remained optimistic, but how could she limit the impact on her people during this challenging time?

\footnotetext{
${ }^{1}$ Copyright (C) 2021, Jacqueline Skryd. This case was prepared for the purpose of class discussion, and not to illustrate the effective or ineffective handling of an administrative situation. This case is published under a Creative Commons BY-NC license. Permission is granted to copy and distribute this case for non-commercial purposes, in both printed and electronic formats.
} 


\section{Economic Opportunity}

\section{Evolution of Community Colleges}

Shortly after she completed college, a long-standing community member named Helen Callier, owner of George's Pools in South St. Petersburg, suggested that Williams look at applying for work at what was then called St. Petersburg Junior College. "There is opportunity there," she said. "There's good pay and opportunities to support your family and do more for your community."

Community colleges in the United States have long served local communities as an affordable option to attain a two-year degree, the steppingstone to a bachelor's level credential and the gateway to higher paying jobs. Developed first in the early 1900s, community colleges were looked to as the means to improve global economic competitiveness, seeing that only $75 \%$ of high school graduates were choosing to further their education at the time. Many students opted, or could only afford, to stay closer to home rather than go to a school far away (AACC, n.d.). The mission of the community college came to be the center of educational opportunity for all who desired to learn.

By 2020 there were over 1,100 community colleges sprawled across the country. Community colleges had evolved to offer workforce-based credentials, including industry certifications, two-year and even four-year degrees, and served as a critical means to driving regional workforce and economic development with their emphasis on applied, technical skills training (Dougherty and Townsend, 2006).

\section{The Florida College System}

Being close to home and being able to help others was important to Dr. Williams. So, she ended up taking the advice of Ms. Callier and applied to work at SPC. Little did she know that she would be entering into one of the largest educational systems in the country. Her chance to impact lives for the better would be far greater than she ever imagined.

By 2020, with 28 colleges, the Florida College System (FCS) represented over 733,000 students. Together with the Florida State University System's 341,000 students, the state served more than 1 million students a year toward an advanced education. With the addition of bachelor's degrees to the mix of program options, Florida colleges began to drop "junior" and "community" from their names. By the late 2010s, all but a few colleges in Florida offered four-year degrees and changed their names, including St. Petersburg Junior College becoming St. Petersburg College.

Much of this growth stemmed from innovations in transfer pathway agreements that were developed between the colleges and their adjacent universities to support easier transition for students between institutions from one degree to the next. The Florida colleges and universities worked hand in hand to ensure the academic quality was up to par in order to offer guaranteed admission into state universities upon graduation with a two-year degree. Florida's guaranteed admission agreements became the 'gold standard' for other systems throughout the country. More than half of FCS graduates were transferring to universities (AFC, n.d.).

At this time, the FCS not only grew but improved in quality. It was recognized several years running as the \#1 College System in the country by U.S. News and World Report (Ziegler, 2019). Several of its colleges earned the Aspen Prize, the country's top community college award for excellence (AFC).

\section{Student Success \& First Time in College}

The FCS's high level of achievement could be attributed to a new way of administrative operations that was coming into play, the implementation of the new Guided Pathways model. In 2015, Florida colleges 
began focusing on the total student to provide better supports to help students graduate. Prior to this time, student retention and completion rates were very low, typically in the teens and twenties. Students were not progressing.

Many community college students were first in their families to go on to college. They didn't have the support or guidance at home to know how to be successful, where to start, or who to turn to. Many had competing priorities of work and family care. Many of them never earned high grades but wanted a better education to improve their opportunities for a better job to support themselves and their families.

Guided Pathways became a national movement that led to the redesign of many community colleges, their practices, programs, and services. Guided Pathways focused on four key areas: 1) mapping pathways to students' end goals; 2) helping students choose and enter a program pathway; 3) keeping students on the path; and 4) ensuring that students were learning (Jenkins, et al, 2018).

This was work that was near and dear to Dr. Williams' heart. How could SPC better support its students to help them finish what they started? How do they focus on student success and not just access?

During this time, Dr. Williams oversaw student services at SPC. As Vice President, she was on the front lines and leading the charge to make these changes so that students had the support structure they needed for tutoring, advising, career exploration, and embedded work experience into courses. Shortly after colleges began implementing the guided pathways model, retention and completion rates started to grow.

\section{College Affordability}

The good news for these students was that the tuition and fees for attending an FCS college was reasonable. A student at an FCS institution could pay as little as $\$ 3,205$ per year toward a degree, compared to $\$ 5,943$ at a state university (FLDOE, 2019).

Even with the cost of higher education as a top public concern, Florida continued to be recognized as one of the most affordable states to obtain an undergraduate degree. The transfer pathways were one of cost savings strategies for students who started out at a community college and finished at the university.

For the previous 10 years, state elected officials had been committed to keeping higher education affordable in Florida. To do this, Florida colleges were restricted from raising tuition. They were also required by statute to periodically review course fee structures. By doing so, colleges often found ways to reduce or eliminate certain fees in alignment with updated program offerings and student supports. The colleges also worked to enhance operational efficiencies by reviewing administrative functions, including reorganizing top-heavy administrative structures.

As a result of these measures, the state achieved the status of being one of the most affordable states for a higher education. While this had been a great benefit for the student, the FCS began to feel the brunt of stagnant tuition revenue, while costs increased. 


\section{Florida's Oldest Community College}

\section{Institutional Landscape}

St. Petersburg College (SPC) was Florida's first community college, established in 1927. Reflecting the national landscape, residents in St. Petersburg, Florida were seeking a local institution for higher learning that could provide them the job skills they needed, but one that they could afford within their modest means. SPC continued to serve in this role over the years and by 2020 was home to over 47,000 students. (SPC Fact Book, 2020). A pioneer of its time, SPC later charted history again in 1997 by becoming one of the first community colleges to establish a robust online program. It grew to be one of the largest in the country. In 2001, SPC became the first community college in Florida, and one of the first in the nation, to offer four-year, workforce-based degrees.

Traditional college students were young, coming straight out of high school, and headed to a university. Community college students were non-traditional. During the 2019-2020 academic year, the average student age at SPC was 27 , with $47 \%$ of the student body over the age of 25 . Nearly a third of them were first in their family to attend college. Almost $75 \%$ of the students attended part-time, $72 \%$ were working, and $35 \%$ had children. Moreover, $76 \%$ were Pell eligible, meaning they met financial need by federal standards. Collectively, the average SPC student could be considered as a lower income, working adult.

In 2017, Dr. Williams joined a short list of leaders at the college, as SPC's seventh president. Not only was she the first female president for the college, she was also the first African American. Born and raised in St. Petersburg, the institution was home to her, always in her backyard, and always her workplace. She had started work at the college in one of the lowest paid positions in the Financial Aid office over 33 years prior.

Her leadership of the College came with the responsibility for nearly 2,500 employees, representing three core groups: 1) faculty (352 full-time and 1,120 adjunct instructors); 2) 428 administrative and professional staff (exempt workers); and 3) 563 career service employees (hourly workers). SPC's faculty were paid competitively for the Tampa Bay region, including some making in the six figures. On the lower end of the salary spectrum lay the career service workers, many of whom made minimum wage, earning less than $\$ 26,000$ a year. These were the employees that were always top of mind when it came to budget changes. At the time when COVID-19 hit, SPC's adjunct faculty had just voted to unionize and negotiations were underway. The full-time faculty were not unionized but were keeping a watchful eye.

\section{The Community of the College}

SPC was the primary local college serving Pinellas County on the west, central coast of Florida. With just under one million residents, Pinellas County was the most densely populated county in the state. In 2019, many of the fastest growing jobs in the region required a college-level credential, yet $58 \%$ of working-age adults in the county had not attained a degree (see Exhibit 1). More than 109,000 had some college and no degree.

The number of people in the county that were just barely able to make ends meet might have been a consequence of the low levels of college attainment. Prior to COVID, over 30\% of the households in Pinellas were Asset Limited, Income Constrained, yet Employed (United Way ALICE Project, 2018). That meant they earned more than the Federal Poverty Level, but less than the basic cost of living. Combined with a $12 \%$ poverty rate, it was evident that just under half of the households $(42 \%)$ were struggling financially (see Exhibit 2). COVID was expected to impact the economic situation even further. By May 2020, the unemployment rate reached 13.4\% (Florida DEO, 2020). Many of those 
unemployed had held lower paying jobs, especially from the hospitality industry. Would these individuals be ready to go back to school and upskill for a better career in the future?

\section{Community of Care}

Dr. Williams was committed to changing lives. Her efforts to operate through a Community of Care were put in place to ensure that the entire SPC family - students and employees - and surrounding communities, had what they needed to lead healthy and productive lives.

Dr. Williams was born to a single mom who was 17 and raised with the help of her grandmother. She grew up in South St. Petersburg, known for being one of the region's poorest neighborhoods. Through abuse, eviction and food insecurity, her mother wanted better for her, and she told her daughter that education was the key. Her family was on welfare, but she never knew she was poor until she went to college.

Attending Clearwater Christian College as the only African American student opened her eyes to many things. There were many times where she felt like an outcast, where she felt sorry for herself, but she refused to lose. "I wanted to prove all of the people wrong that didn't think I could make it," she said. "Like I tell everyone - it's not where you start, it's where you finish." It wasn't an easy journey, but Williams was supported by many people over the years that stood in the gap to help her through.

"I like being a part of changing somebody's life," she shared. "Our students have opportunity. If we can get them to school, help keep them in school and on their way to a great career that supports their families, we will have changed generational poverty and economic prosperity for our region."

She felt the same about her employees. Dr. Williams had worked with so many of the same people over the years. She respected everyone and wanted them to feel that way in return. She wanted to make sure that at SPC, employees were recognized, valued, and heard.

The Community of Care became the way of treating people and doing business at St. Petersburg College. She made sure there was broad representation in decision-making and strategic planning - from maintenance and advisors, to faculty and higher-level administration. The strategy helped to prevent a top down structure.

\section{Fiscal Health}

Just prior to Dr. Williams' start as president, unstable state funding and flat tuition rates were eventually catching up to the college's bottom line. Revenues were no longer covering expenses. The financial strain removed the ability to offer raises, burdening its employees as cost of living continued to climb. Meanwhile, frustrations among faculty and staff were brewing, and eventually the adjunct faculty at the college voted to unionize in 2019.

Faced with declining enrollment, the college worked to realign priorities, expenses, and redirect attention to growing new programs and increase enrollment. This included a review of the college's footprint and space utilization, including increasing business rentals and selling properties where it made sense. This was a meaningful strategy because the college operated 10 campus sites and over 120 buildings. 
While SPC experienced lower enrollment the last few years, the local technical school, Pinellas Technical College, saw its enrollment rise. The same was happening across the Bay at Hillsborough Community College, where a new campus helped boost enrollment in its rural areas.

Dr. Williams believed there were two key reasons why SPC's enrollment was declining: 1) the college was not offering relevant programs that were aligned with workforce demands; and 2) the college was not developing a student-centered course schedule using various modalities to meet student needs. Both of those challenges became quick priorities and strategic initiatives. The employees knew that increasing enrollment through focused recruitment and retention efforts meant an increase in revenue. The shift of focus to enrollment was also a key strategy to be more in control of the college's own financial future.

\section{Resource Dependency}

\section{Generating Revenue}

In her few short years since becoming president, Dr. Williams and her team had made progress regarding the college budget through better planning. To Dr. Williams, it was the most important area of focus. "We were on a good path before COVID," she said. "We made the right moves to right-size the college and were making strides to boost enrollment and improve retention, both of which were drivers of tuition and fee revenue."

At the time of COVID, SPC earned revenues in three ways - 50\% came from state funding; $43 \%$ came from tuition and fees; and 7\% from auxiliary funds such as space rental and paid events (see Exhibit 3 ).

SPC remained heavily reliant on state funding for its revenue, which caused uncertainty every year for where the college would stand at the beginning of its fiscal year, which started July 1 . By 2020, state funds equaled $\$ 72$ million of the college's operating budget. Over the past several years, it became clear to Dr. Williams that the only revenue the college could control in many ways, was its enrollment and auxiliary services. So, they planned better, were more creative, and worked to reduce resource dependency on the state.

Educational funding from the state required approval by the legislature and the Governor. By state statute, funds available for allocation to the Florida College System were determined by; 1) what was budgeted under the General Appropriations Act as base funds; and 2) Performance-Based Incentives. At the time, performance incentives were awarded to the colleges using metrics adopted by the Florida Department of Education. The metrics included retention rates; program completion; graduation rates; postgraduation employment; and wages. Each year, it was up to the FLDOE to set the metric calculations, which could shift year to year.

\section{Florida Legislative Session}

In 2020, Florida's state lawmakers held their legislative session early as it was an election year. The state rotated its session dates every other year for that reason. By law, its senate and house of representatives would meet for sixty consecutive days. The only job they had to accomplish was to approve the budget. On March 19, 2020, Florida's legislature adjourned its regular session with an approved budget. In contrast, many states during that time had to suspend their sessions because of the pandemic. Florida just squeaked by before the Governor issued a shelter at home order on March 24.

Even though the two sides of the legislature came to an agreement and approved the budget, the Governor still needed to sign off. By the middle of June, the $\$ 93.2$ billion proposed budget that funded the state's agencies and many service organizations through appropriations, was still up in the air. 
With the new fiscal year set to begin July 1, determining the college's budget for the coming year was going to be a monumental challenge. Dr. Williams stated:

"In a normal year, we were able to deal with the unknowns of where the state was going to land with the budget and performance estimates, and project where we thought we would land. Although the budget was always an unknown, COVID's impact was implausible. With all the losses and compounded expenses, how bad was the state going to be hit? How bad were we going be hit?"

\section{A Perfect Storm}

\section{Technology Expenses}

Dr. Williams knew SPC was well prepared to go fully online. It maintained one of the largest online course portfolios across the Florida College System. However, there were still 1,800 courses that needed to be transitioned to the online format. Because the timing of the Governor's order came only days after the return from Spring Break when the college was closed, the faculty and staff had only a few short days to make the shift. In the days ahead, the college worked to expand its licenses to operate online proctored exams and course delivery tools, including simulated technologies in place of labs.

Access to technology was a critical need for many students and employees. The college distributed nearly 600 laptops, Wi-Fi hotspots and webcams for those who needed it to help continue student learning and operations online.

The technology expense to get everything up and running and maintained was in the millions, levels SPC had not accounted for in its annual budget.

\section{Unknown Revenue}

When COVID-19 hit, SPC's financial status had been stable, but even a small decline in enrollment and state funding would be significant setback. As a result of COVID, at the Board of Trustee meeting on May 19, 2020, Dr. Williams reported that tuition revenue was projected to be $\$ 1.25$ million less than what was budgeted (see Exhibit 4).

With enrollment as a key revenue driver, losing existing students and potentially future students, would impact the college's budget and ability to maintain payroll at its current level. Compounding the fiscal implications was the timing of legislative session. The college depended on about $50 \%$ of its funding from state dollars that had not yet been approved for the coming year. These funds would also be at-risk for a cut, with the anticipation of state sales taxes taking a bit hit. However, the federal government had been preparing to infuse much needed stimulus funds to keep things afloat.

\section{Enrollment}

For the rest of the spring semester, Dr. Williams and her team kept a close eye on the students they were losing from course withdrawals. In many cases, students were uncomfortable taking online classes and wanted to wait until the school opened again in order to be face-to-face. In other cases, their life situation was so heavily impacted, continuing their studies was the last thing on their minds. At the very beginning of the quarantine, over 5,000 SPC students responded to a survey that they were recently unemployed 
because of COVID-related layoffs. Students started applying to the SPC Foundation for emergency assistance funding to help with food, housing, medical, and utility bills.

By the end of the spring semester, SPC realized a loss of nearly $12 \%$ of its students. There was a proposal by the team to offer those students the ability to retake their courses in the fall at no cost. The calculated loss of revenue by moving forward with this plan was an estimated $\$ 4$ million.

The news was brighter when it came to enrollment for summer. The rates were flat compared to summer semester of the previous year. Had the students they lost in spring decided to come back? Were students choosing to enroll at SPC instead of elsewhere?

The spring and summer numbers were good for closing out the fiscal year without a loss. But what was next year going to look like? Would enrollment be strong in the fall or would SPC face a critical loss? Even more important, what was the state allocation going to be?

\section{State Budget}

By the middle of June, the Governor still hadn't approved the state budget brought forward by the legislature in March. The state had lost $\$ 900$ in state sales tax between March and April alone, and it was expending more and more each day in unemployment and other essential costs that were unplanned.

At the same time, the federal government had approved the CARES Act intended to pump billions of stimulus funds into the economy, including direct distribution to the states. The state of Florida was set to receive $\$ 8$ million, but there were still large amounts that the feds had yet to allocate. Was the Governor waiting to see just how much it would receive in federal aid before signing off on the budget or vetoing certain items? Or was it even a necessary maneuver with more than $\$ 4$ billion available in reserves?

\section{Budgeting Ahead}

As the June $30^{\text {th }}$ year-end date approached, Dr. Williams had no idea what her budget was going to be; what the state was going to ultimately contribute; what enrollment was going to be; and how many losses were going to be incurred in the end.

SPC was required to submit its 2020-2021 budget to the state for approval by the end of June. But how much should be budgeted with so many uncertainties? A shining light was that SPC was to receive \$6.4 million of its own stimulus funds, but it wasn't clear what the college could spend it on, and it only had a year to do it. Additionally, the college had accumulated $\$ 14$ million in reserves for a rainy day.

It was clear that the president had to plan for a shortfall for the next fiscal year. But how much?

Dr. Williams brought her leadership team together to come up with different scenarios. They had to move forward. Their Board of Trustees had to approve the budget before sending it to the state. In the end, they focused on enrollment circumstances. Legislative feedback at the time was that state funding should remain flat. Planning ahead safely, the team budgeted to be $10 \%$ down in tuition revenue (see Exhibit 5). They were able to come up with $\$ 3.5$ million in savings to offset this loss through a mix of cost-cutting strategies. At this point, there was no impact to employment levels. But what if the state did end up cutting funding to the college system? What if enrollment was less than budgeted? The college had a small contingency to offset some additional losses, but any significant fluctuations would require major decisions. With $80 \%$ of its budget being spent on personnel, one thing was for sure, a cost savings to personnel was the only area left that could make a dent. 


\section{Courage over Comfort}

All along during the pandemic, one of the biggest priorities for Dr. Williams was to keep employees employed as long as college resources would allow. She knew any financial shortfalls above and beyond what was already budgeted would trigger an impact on the college family. She said:

"As president I recognized that this was a business decision I had to make. Separating emotions and friendships is very hard. I'm the one preaching a Community of Care and being kind to our employees. But I needed, and my leadership team needed, to make those bold and brave decisions."

The team calculated ways to come up with another $10 \%$ cut to the budget. There were several options that were considered as a next step. All of which would impact employees.

1. Option 1: Furlough employees - temporarily for four weeks out of the first four months of the school year.

The Pros: It would save the most money, calculated at an estimated \$3.52 million. It would also offer cash flow needed for the beginning of the fiscal year.

The Cons: It was a complex approach. Will furloughed employees be able to draw unemployment? This option would impact employees unequally - for example, faculty would still need to teach. Would this trigger new teaching modalities to support enrollment? Additionally, this approach would result in a reduction in force while running operations fully, online and on campus. Would the workload increases have unintended consequences on staff, including health implications? Would they quit?

2. Option 2: Institute pay cuts across the board

The Pros: It would save an estimated $\$ 3.36$ million. It would keep people earning wages. It would also be a less complicated approach, easily adjusting the percent of the pay cut and month-tomonth timeframe and gives the president more time to make the decision.

The Cons: The employees hadn't seen raises in 6 years. What would this do to staff morale, especially those lowest paid? Would there be an influx of retirements and staff leaving for work elsewhere, leaving critical jobs unfilled, impacting teaching, learning, and service delivery? Would student performance be impacted as a result? Would this trigger unionization by faculty on top of the adjunct faculty union negotiations?

3. Option 3: Use reserves to offset losses

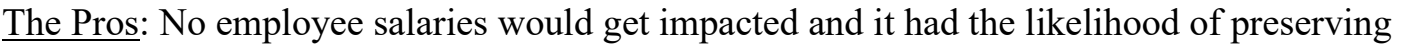
employee morale.

The Cons: It would reduce safety net funds available for other emergencies, including hurricanes, when a more active than normal season was projected; and unexpected insurance hikes, when the College was in the middle of renewing its self-insurance plan and potential COVID costs were probable. What would happen if state funding cuts much higher than projected and budgeted enrollment goals weren't met? Would the reserves end up depleted? 
4. Option 4: implement a combination of choices or a separate option altogether

It was important to Dr. Williams that she do right by her people, but the decision wasn't going to be easy. "It was going to take courage over comfort," she declared. So, what was the right option? 


\section{References}

American Association of Community College (AACC). (n.d.). History of Community Colleges. Retrieved June 6, 2020, from https://www.aacc.nche.edu/research-trends/history-of-community-colleges/

Association of Florida Colleges (AFC). (n.d.). Fund Florida's Colleges. Retrieved June 6, 2020, https://fundflcolleges.com/

Dougherty, K. J., \& Townsend, B. K. (2006). Community college missions: A theoretical and historical perspective. New Directions for Community Colleges, 2006(136), 5-13.

Florida Department of Economic Opportunity (May 2020). Local Area Unemployment Statistics by Month (Workforce Region 14). Retrieved June 6, 2020, from https://floridajobs.org/workforcestatistics/data-center/statistical-programs/local-area-unemployment-statistics

Florida Department of Education (FLDOE). (2019, December). Affordability in the Florida College System. http://www.fldoe.org/core/fileparse.php/7724/urlt/19FCSAffordReport.pdf

Jenkins, P. D., Lahr, H. E., Fink, J., \& Ganga, E. C. (2018). What we are learning about guided pathways.

St. Petersburg College. (2020). Fact Book. Retrieved June 13, 2020, from https://www.spcollege.edu/Documents/community/Web_Factbook_19-20.pdf

United Way ALICE Project (2018). ALICE: A Study of Financial Hardship in Florida. Retrieved June 6, 2020, from https://www.dropbox.com/s/x03dik49thmrz6r/18UW ALICE Report FL Refresh11.14.18_Final_Lowres.pdf?dl=0

Ziegler, Brett. (2019). Higher Education Rankings: Measuring which states are the most educated. U.S. News and World Report. Retrieved June 13, 2020, from https://www.usnews.com/news/beststates/rankings/education/higher-education

\section{Acknowledgements}

I would like to gratefully acknowledge the contributions of Dr. Tonjua Williams in the creation of this case. Her openness and commitment to sharing the information will benefit many who use this case for professional learning and development. St. Petersburg College is a public institution of the Florida College System, a division of the Florida Department of Education. Due to Florida's very broad public records law, most written communications to or from College employees regarding college business are public records. 


\section{Biography}

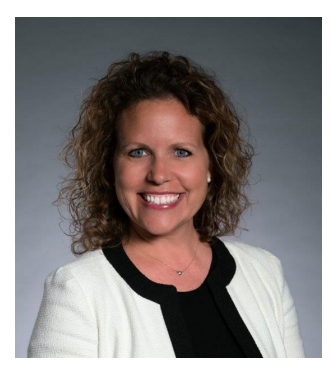

Jacqueline Skryd is Chief of Staff at St. Petersburg College and Doctor of Business Administration student at the University of South Florida. She holds a Bachelor's in International Studies, Business and French, from the University of Michigan. She currently serves as Chair of Leadership Tampa Bay, and on the Leadership Council for the LEAP Tampa Bay Local College Access Network. Her planned research is in the area of human capital and workforce improvement strategies. 


\section{Exhibit 1: Adults with Some College Credit, but No Degree}

\section{About this Indicator}

This indicator is the percentage of working-age adults (ages 25-64) who have earned some college credit, but did not finish a degree. Completing a degree or credential helps workers progress in their career.

\section{Pinellas County 5}

As of 2016, 2.1 million adult Floridians had started college but not completed a degree program. Five percent of these Floridians, or approximately 109,000 individuals, lived in Pinellas County. When examining the counties with the largest percentages of its residents with some college credit, but no degree, Pinellas ranks $29^{\text {th }}$ among Florida's 67 counties.

While Pinellas County residents ages 25-64 have higher educational attainment than residents of Florida and United States, Pinellas has a higher percentage of adults with some college credit, but no degree than both the United States and Florida.

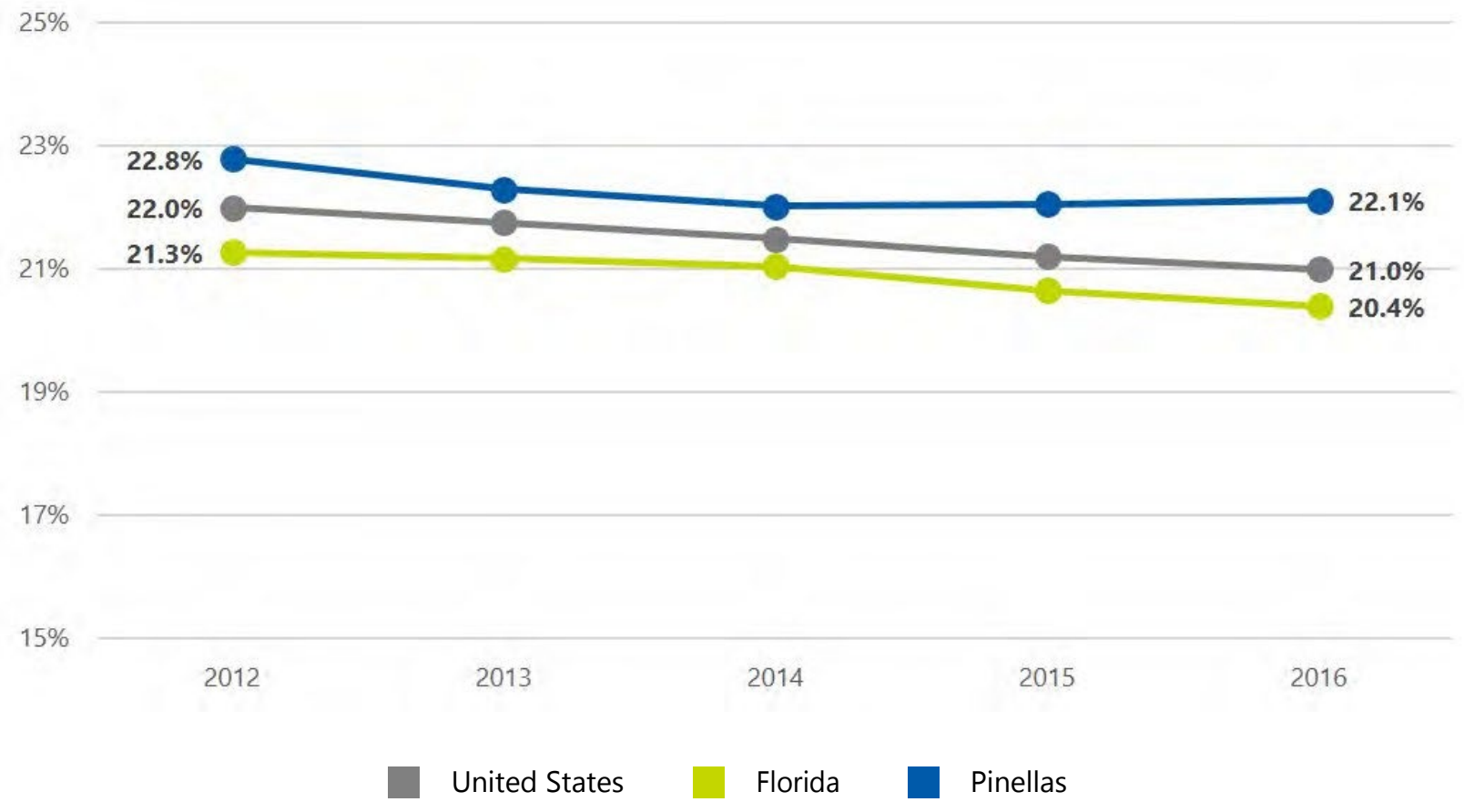

Source: Pinellas County Community Indicator Report. The State of Postsecondary Access and Attainment in Pinellas County. St. Petersburg, FL: Florida College Access Network for Pinellas Education Foundation and LEAP Tampa Bay College Access Network, 2018. 


\title{
ALICE IN PINELLAS COUNTY
}

\author{
2016 Point-in-Time Data
}

Population: $960,730 \cdot$ Number of Households: 407,268

Median Household Income: \$50,036 (state average: \$50,860)

Unemployment Rate: $5.8 \%$ (state average: $6.0 \%$ )

ALICE Households: 30\% (state average: $32 \%$ ) Households in Poverty: 12\% (state average: $14 \%$ )

\section{How has the number of ALICE households changed over time?}

\section{ALICE is an acronym for Asset}

Limited, Income Constrained,

Employed - households that earn more than the Federal Poverty

Level, but less than the basic cost of living for the county (the ALICE Threshold). Combined, the number of ALICE and poverty-level households equals the total population struggling to afford basic needs. The number of households below the ALICE Threshold changes over time; households move in and out of poverty and ALICE status as their circumstances improve or worsen. The recovery, which started in 2010, has been uneven across the state. Conditions have improved for some families, but with rising costs, many still find themselves struggling.

\section{What types of households are struggling?}

The way Americans live is changing. There are more different family and living combinations than ever before, including more adults living alone, with roommates, or with their parents. Families with children are changing: There are more non-married cohabiting parents, same-sex parents, and blended families with remarried parents. The number of senior households is also increasing. Yet all types of households continue to struggle: ALICE and povertylevel households exist across all of these living arrangements.

\section{Households by Income, 2010 to 2016}

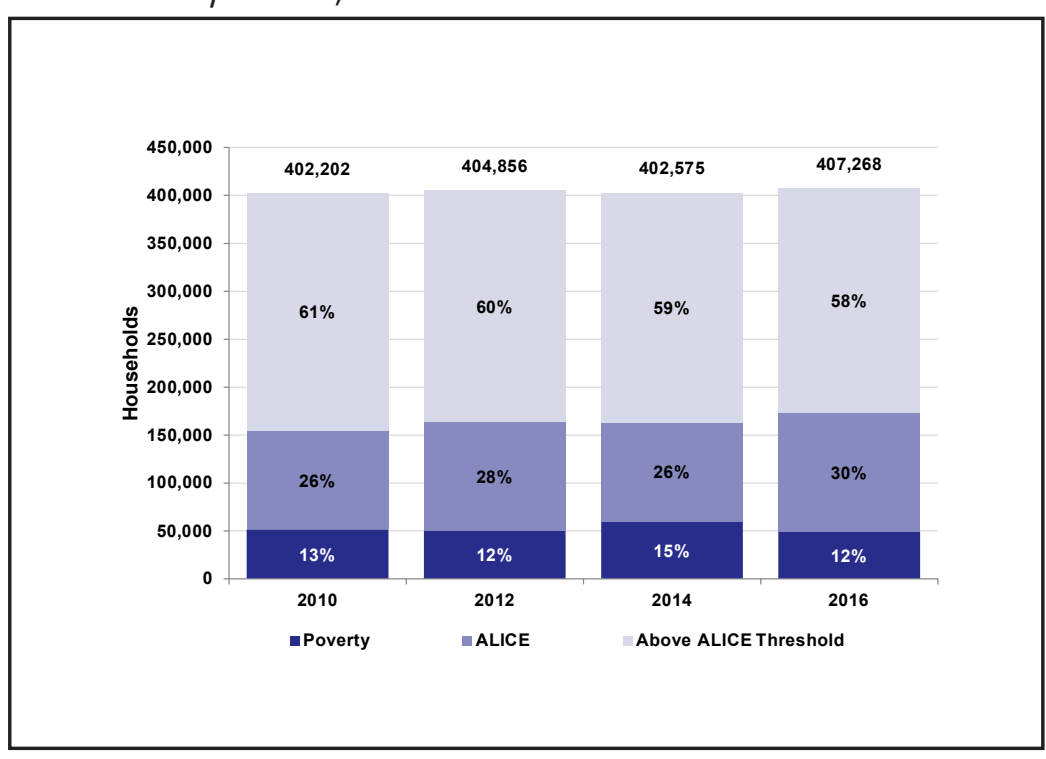

Household Types by Income, 2016

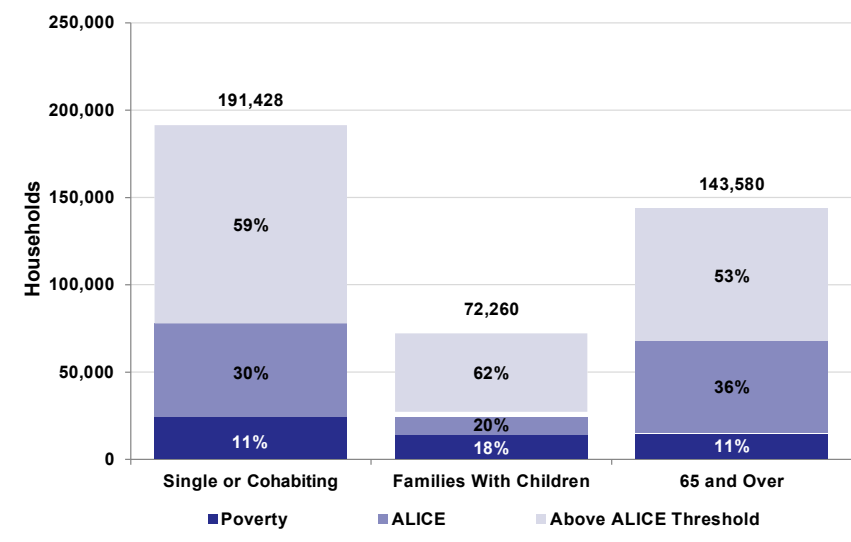




\section{Why do so many households struggle?}

The cost of living continues to increase...

The Household Survival Budget reflects the bare minimum that a household needs to live and work today. It does not include savings for emergencies or future goals like college. In 2016, costs were well above the Federal Poverty Level of $\$ 11,880$ for a single adult and $\$ 24,300$ for a family of four. Family costs increased by 15 percent statewide from 2010 to 2016 , compared to 9 percent inflation nationally.

\begin{tabular}{|c|c|c|}
\hline \multicolumn{3}{|c|}{ Household Survival Budget, Pinellas County } \\
\hline & SINGLE ADULT & $\begin{array}{l}2 \text { ADULTS, } 1 \text { INFANT, } \\
1 \text { PRESCHOOLER }\end{array}$ \\
\hline \multicolumn{3}{|l|}{ Monthly Costs } \\
\hline Housing & $\$ 668$ & $\$ 992$ \\
\hline Child Care & $\$-$ & $\$ 1,160$ \\
\hline Food & $\$ 164$ & $\$ 542$ \\
\hline Transportation & $\$ 322$ & $\$ 644$ \\
\hline Health Care & $\$ 196$ & $\$ 726$ \\
\hline Technology & $\$ 55$ & $\$ 75$ \\
\hline Miscellaneous & $\$ 163$ & $\$ 454$ \\
\hline Taxes & $\$ 224$ & $\$ 401$ \\
\hline Monthly Total & $\$ 1,792$ & $\$ 4,994$ \\
\hline ANNUAL TOTAL & $\$ 21,504$ & $\$ 59,928$ \\
\hline Hourly Wage & $\$ 10.75$ & $\$ 29.96$ \\
\hline
\end{tabular}

\section{...and wages lag behind}

Employment and wages vary by location; firms generally pay higher wages in areas with a higher cost of living, although those wages still do not always cover basic needs. Employment and wages also vary by firm size: Large firms tend to offer higher wages and more job stability; smaller businesses can account for more jobs overall, especially in rural areas, but may pay less and offer less stability. Medium-size firms pay more but typically employ the fewest workers.

Private-Sector Employment by Firm Size With Average Annual Wages, 2016

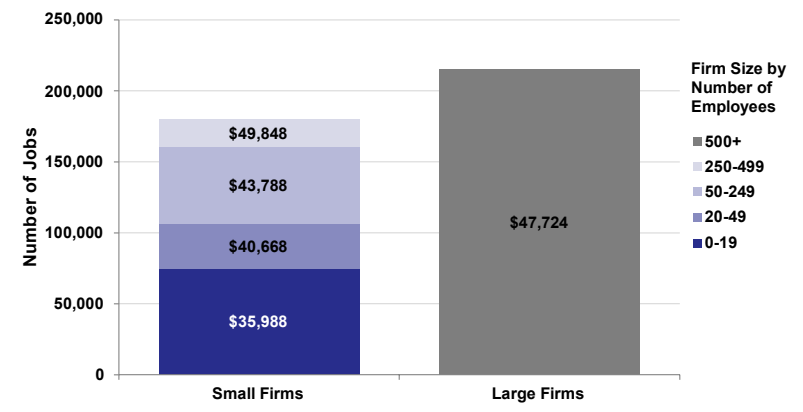

Sources: 2016 Point-in-Time Data: American Community Survey. ALICE Demographics: American Community Survey; the ALICE Threshold. Budget: U.S. Department of Housing and Urban Development; U.S. Department of Agriculture; Bureau of Labor Statistics; Internal Revenue Service; Tax Foundation; and Florida Department of Education, 2016

\begin{tabular}{|l|c|c|}
\multicolumn{3}{|c|}{ Pinellas County, 2016} \\
\hline \multicolumn{2}{|l|}{} \\
\hline Town & Total HH & $\begin{array}{c}\text { \% AllCE } \\
\text { Poverty }\end{array}$ \\
\hline Bardmoor CDP & 3,884 & $46 \%$ \\
\hline Bay Pines CDP & 1,501 & $42 \%$ \\
\hline Bear Creek CDP & 926 & $42 \%$ \\
\hline Belleair & 1,722 & $19 \%$ \\
\hline Belleair Beach & 739 & $24 \%$ \\
\hline Belleair Bluffs & 1,191 & $45 \%$ \\
\hline Boca Ciega CCD & 30,727 & $40 \%$ \\
\hline Clearwater & 45,459 & $49 \%$ \\
\hline Clearwater CCD & 141,218 & $46 \%$ \\
\hline Dunedin & 16,818 & $45 \%$ \\
\hline East Lake CDP & 13,065 & $26 \%$ \\
\hline Feather Sound CDP & 1,723 & $27 \%$ \\
\hline Greenbriar CDP & 1,104 & $34 \%$ \\
\hline Gulfport & 5,935 & $48 \%$ \\
\hline Harbor Bluffs CDP & 1,221 & $24 \%$ \\
\hline Indian Rocks Beach & 2,204 & $31 \%$ \\
\hline Indian Shores & 850 & $38 \%$ \\
\hline Kenneth City & 1,754 & $51 \%$ \\
\hline Largo & 38,718 & $51 \%$ \\
\hline Lealman CDP & 8,651 & $65 \%$ \\
\hline Madeira Beach & 2,348 & $41 \%$ \\
\hline $\begin{array}{l}\text { North Redington } \\
\text { Beach }\end{array}$ & 769 & $32 \%$ \\
\hline Oldsmar & 5,153 & $35 \%$ \\
\hline Palm Harbor CDP & 26,462 & $37 \%$ \\
\hline Pinellas Park & 20,942 & $50 \%$ \\
\hline Redington Beach & 709 & $20 \%$ \\
\hline Redington Shores & 1,215 & $33 \%$ \\
\hline Ridgecrest CDP & 972 & $66 \%$ \\
\hline Safety Harbor & 7,242 & $35 \%$ \\
\hline Seminole & 8,441 & $41 \%$ \\
\hline South Highpoint CDP & 1,781 & $63 \%$ \\
\hline South Pasadena & 3,347 & $57 \%$ \\
\hline St. Pete Beach & 5,005 & $33 \%$ \\
\hline St. Pete Beach CCD & 8,455 & $34 \%$ \\
\hline St. Petersburg & 109,832 & $41 \%$ \\
\hline St. Petersburg CCD & 167,459 & $47 \%$ \\
\hline Tarpon Springs & 10,051 & $45 \%$ \\
\hline Tarpon Springs CCD & 57,929 & $37 \%$ \\
\hline Tierra Verde CDP & 1,680 & $15 \%$ \\
\hline Treasure Island & 3,567 & $36 \%$ \\
\hline West Lealman CDP & 7,495 & $58 \%$ \\
\hline
\end{tabular}

Note: Municipal-level data is 1 - and 5-year averages for Incorporated Places and County Subdivisions, which include Census Designated Places (CDP) and Census County Divisions (CCD). Totals do not match county-level numbers because some places cross county borders, geographies may overlap,
data is not available for the smallest towns, and data is not available for the smallest towns, an county-level data is often 1-year estimates. 


\section{Exhibit 3: SPC Revenue \& Expense Summary 2019-2020}

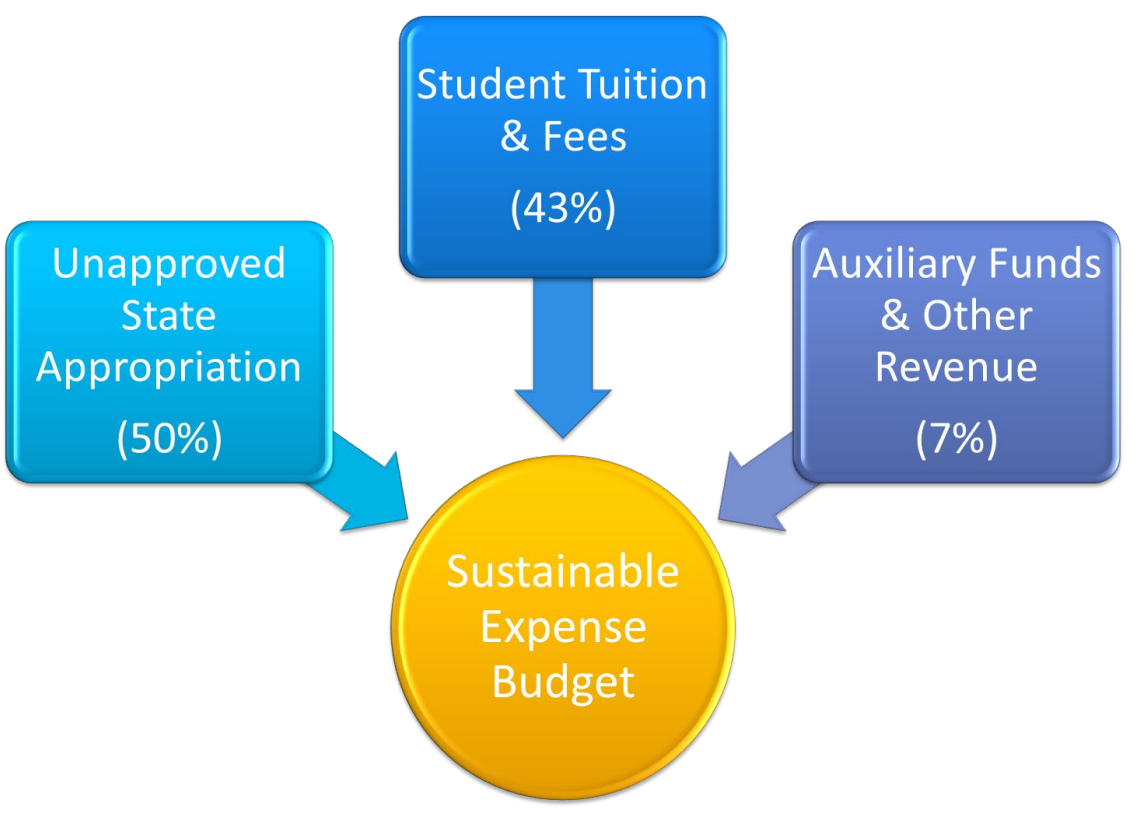

\section{9-2020 Revenue:}

- Tuition \& fees - $\$ 62.5 \mathrm{M}(43 \%)$

- State funding - $\$ 72.6 \mathrm{M}(50 \%)$

- Auxiliary resources - $\$ 10.1 \mathrm{M}(7 \%)$

Top Expense: Personnel - \$116M (80\%)

Source: SPC Board of Trustees Meeting, May 19, 2020 
MUMA CASE REVIEW

\section{Exhibit 4: SPC Statement of Revenues, Expenses and Changes in Net Position - 6 Year Comparison}

\begin{tabular}{|c|c|c|c|c|c|c|c|c|c|c|c|c|}
\hline \multicolumn{13}{|c|}{ Statement of Revenues, Expenses and Changes in Net Position } \\
\hline & \multicolumn{2}{|c|}{2019} & \multicolumn{2}{|c|}{2018} & \multicolumn{2}{|c|}{2017} & \multicolumn{2}{|c|}{2016} & \multicolumn{2}{|c|}{2015} & \multicolumn{2}{|c|}{2014} \\
\hline & College & Component Units & College & Component Units & College & Component Units & College & Component Units & College & Component Units & College & Component Units \\
\hline \multicolumn{13}{|l|}{$\begin{array}{l}\text { REVENUES } \\
\text { Operating Revenues: }\end{array}$} \\
\hline Student Tuition and & $\$ \quad 39,900,218$ & $\$$ & & $\$$ & & $\$$ & & $\$$ & & & & \\
\hline 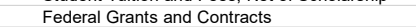 & $\$ \quad 612,104$ & $s$ & 30,314 & $\$$ & 286,188 & $\$$ & $4,42,391$ & $\$$ & 42,174,317 & $\$$ & 756,608 & \\
\hline State a & $1,485,632$ & $\$$ & 143,118 & $\$$ & $1,396,198$ & $\$$ & $1,562,940$ & $\$$ & $1,746,981$ & $\$$ & $1,836,111$ & $\$$ \\
\hline Nongove & 511,060 & $\$$ & 523,839 & $\$$ & 368,616 & $\$$ & 870,565 & $\$$ & $1,000,593$ & $\$$ & 681,140 & $\$$ \\
\hline Departments & $2,077,128$ & $\$$ & $2,046,688$ & $\$$ & $1,740,495$ & $\$$ & $2,974,251$ & $\$$ & $3,070,554$ & $\$$ & $3,216,469$ & $\$$ \\
\hline Auxiliary & $2,565,237$ & $\$$ & $2,667,574$ & $\$$ & $3,051,011$ & $\$$ & $3,432,144$ & $\$$ & $3,434,449$ & & $3,336,071$ & \\
\hline Other Operat & $2,087,885$ & $3,576,447$ & $1,900,636$ & $3,628,497$ & $1,808,685$ & $3,480,058$ & 282,118 & $3,841,652$ & 156,717 & $3,564,495$ & 104,566 & $3,137,507$ \\
\hline Total Operating Revenues & $49,239,264$ & $3,576,447$ & $49,054,852$ & $3,628,497$ & $50,173,988$ & $3,480,058$ & $51,831,387$ & $3,841,652$ & $52,121,247$ & $3,564,495$ & $51,121,647$ & $3,137,507$ \\
\hline \multicolumn{13}{|l|}{ EXPENSES } \\
\hline inses: & & & & & & & & & & & & \\
\hline Persc & $4,666,459$ & $\$$ & $\$ \quad 129,257,181$ & $\$$ & \& $132,958,308$ & $\$$ & $\$ 130,073,059$ & $\$$ & $125,970,610$ & $s$ & $\$ \quad 124,302,356$ & $\$$ \\
\hline alvers & $39,366,517$ & $3,995,258$ & $38,412,429$ & $3,282,033$ & $\$ \quad 30,354,046$ & $2,994,716$ & $34,046,990$ & $2,972,139$ & $35,111,496$ & $2,959,944$ & $32,660,896$ & $2,597,872$ \\
\hline Utilities and Communications & $6,449,418$ & $\$$ & $6,221,518$ & & $5,773,212$ & $\$$ & $6,154,317$ & $\$$ & $6,536,432$ & & $6,327,450$ & \\
\hline Contra & $14,312,102$ & $1,846,244$ & $12,354,449$ & $1,950,663$ & $12,998,976$ & 41,322 & $14,643,223$ & 38,144 & 12,60 & 61,954 & $12,029,801$ & 50,817 \\
\hline Oth & & $\$$ & $9,542,337$ & $\$$ & $8,206,270$ & $1,918,380$ & $8,738,639$ & $2,067,437$ & & $2,185,745$ & $8,658,650$ & 831,989 \\
\hline $\begin{array}{l}\text { Materials and } \\
\text { Depreciation }\end{array}$ & $\begin{array}{l}10,383,536 \\
11,116,245\end{array}$ & 20,549 & $\begin{array}{l}10,959,506 \\
11197801\end{array}$ & 24,872 & $\begin{array}{l}11,852,294 \\
10,848,45\end{array}$ & 27,413 & $\begin{array}{l}16,146,350 \\
11111941\end{array}$ & 33,520 & $15,859,999$ & 31,271 & $\begin{array}{l}13,797,055 \\
10,196,810\end{array}$ & 33,173 \\
\hline Total Operating Expenses & $\begin{array}{l}\quad 217,466,641 \\
\end{array}$ & $5,862,051$ & \& $\quad 217,945,221$ & $5,257,568$ & $\$ \quad 212,991,251$ & $4,981,831$ & \begin{tabular}{|l|l|} 
S & 220.921 .519 \\
\end{tabular} & 511240 & \$ $\quad 215.532 .784$ & 5.328 .914 & $\begin{array}{lr}\text { S } & 207.973 .018\end{array}$ & 4513851 \\
\hline Operating Income (Loss) & $\$ \quad(168,227,377)$ & $(2,285,604)$ & $\$ \quad(168,890,369)$ & $(1,629,071)$ & $\$ \quad(162,817,263)$ & $(1501773)$ & & & & & & 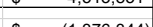 \\
\hline \multirow{2}{*}{\multicolumn{13}{|c|}{ NONOPERATING REVENUES (EXPENSES) }} \\
\hline & & & & & & & & & & & & \\
\hline State Noncapital Appropriations & $\$ 72,364,457$ & $\$$ & $\$ \quad 72,055,542$ & $\$$ & $73,295,190$ & $\$$ & $71,683,251$ & $\$$ & $69,507,154$ & $\$$ & $67,506,879$ & $\$$ \\
\hline ncial Aid & & $\$$ & 58,43 & $\$$ & & $\$$ & & $\$$ & & $\$$ & & \\
\hline Gifts and Gra & $15,610,863$ & 60,873 & $15,175,313$ & 213,969 & $14,842,644$ & 50,425 & $17,217,830$ & 136,381 & $15,341,510$ & $\begin{array}{r}77,143 \\
2389,273\end{array}$ & $13,691,864$ & 34,406 \\
\hline $\begin{array}{l}\text { Investment In } \\
\text { Net Gain Los }\end{array}$ & $\begin{array}{r}642,407 \\
20,816\end{array}$ & $\begin{array}{r}607,320 \\
2.070,171\end{array}$ & $\begin{array}{l}405,236 \\
(8445)\end{array}$ & $\begin{array}{r}465,235 \\
7.674,332\end{array}$ & $\begin{array}{r}371,143 \\
(235554) \\
\end{array}$ & $\begin{array}{r}464,173 \\
8,480,788\end{array}$ & & $(3,084,608)$ & 310,277 & 3,389,373 & 745,917 & $7,602,525$ \\
\hline $\begin{array}{l}\text { Net Gain } \\
\text { Other Non }\end{array}$ & 20,816 & $2,010,1 / 1$ & $(8,445)$ & $1,6 / 4,332$ & $(235,854)$ & $\begin{array}{l}8,680,188 \\
619,096\end{array}$ & 14,026 & $\$$ & 29,603 & $\$$ & 18,563 & 6,425 \\
\hline Gain on Dispos & $\begin{array}{r}5,000 \\
\end{array}$ & $\$$ & $\$$ & $\$$ & 90,650 & $\$$ & 359,900 & $\$$ & $\begin{array}{r}34,001 \\
\end{array}$ & $\$$ & & $\$$ \\
\hline Interest on Capital Asset-Re & $(1,082,064)$ & & $1,071,875$ & $\$$ & $(1,196,353)$ & & $(1,265,323)$ & $\$$ & $(1,250,670)$ & & $(1,308,596)$ & \\
\hline Net Nonoperating Revenues (Expenses) & $\$ \quad 147,207,475$ & $2,738,364$ & $\$ \quad 144,988,860$ & $8,353,536$ & $\$ \quad 138,107,925$ & $9,614,482$ & $\$ \quad 145,921,847$ & $(2,948,227)$ & $\$ 145,200,167$ & $3,466,516$ & $\$ \quad 139,564,053$ & $7,643,356$ \\
\hline Income (Loss) Before Other Revenues & $\$ \quad(21,019,902)$ & 452,760 & $\$ \quad(23,901,509)$ & $6,724,465$ & $\$ \quad(24,709,338)$ & $8,112,709$ & $\$ \quad(23,168,285)$ & $(4,217,815)$ & $\$ \quad(18,211,370)$ & $1,792,097$ & $\$ \quad(17,287,318)$ & $6,267,012$ \\
\hline State $\mathrm{C}$ & $6,913,732$ & $\$$ & $10,336,093$ & $\$$ & $13,793,817$ & $\$$ & $2,313,271$ & $\$$ & $4,433,484$ & $\$$ & $4,637,615$ & $\$$ \\
\hline Capital Gran & $8,208,620$ & $\$$ & $9,283,390$ & $\$$ & $13,037,824$ & $\$$ & $8,564,381$ & $\$$ & $7,764,186$ & (200180 & $6,922,587$ & $\$$ \\
\hline Additions to Endowments & $\$$ & $2,544,585$ & $\$$ & 672,714 & $\$$ & 274,628 & $\$$ & 239,130 & $\$$ & 330,180 & $\$$ & 639,738 \\
\hline Total Other Revenues & $\$ 15,122,352$ & $\$ 2,544,585$ & $\$ 19,619,483$ & $\$ \quad 672,714$ & $\$ 26,831,641$ & 274,628 & $\$ 10,877,652$ & $\$ \quad 239,130$ & $\$ 12,197,670$ & $\$ \quad 330,180$ & $\$ 11,560,202$ & 639,738 \\
\hline Increase (Decrease) in Net Position & $\$ \quad(5,897,550)$ & $2,997,345$ & $(4,282,026)$ & $7,397,179$ & $2,122,303$ & $8,387,337$ & $\$ \quad(12,290,633)$ & $\$(3,978,685)$ & $(6,013,700)$ & $\$ 2,122,277$ & $(5,727,116)$ & $\$ 6,906,750$ \\
\hline Net Position, Beginning of Year & $\$ 209,743,874$ & $\$ \quad 73,890,547$ & $\$ \quad 214,025,900$ & $\$ \quad 66,493,368$ & $\$ \quad 234,948,235$ & $\$ \quad 58,106,031$ & $\$ \quad 247,238,868$ & $\$ \quad 62,084,716$ & $\$ \quad 253,252,568$ & $59,962,439$ & $\$ \quad 301,288,329$ & $53,055,689$ \\
\hline Net Position, End of Year & $\$ \quad 203,846,324$ & $\$ \quad 76,887,892$ & $\$ \quad 209,743,874$ & $73,890,547$ & $\$ \quad 237,070,538$ & $\$ \quad 66,493,368$ & $\$ \quad 234,948,235$ & $58,106,031$ & $\$ \quad 247,238,868$ & $62,084,716$ & $\$ \quad 295,561,213$ & $59,962,439$ \\
\hline
\end{tabular}




\section{Exhibit 5: SPC Tuition Revenue Fiscal Year Projections 2019-2020}

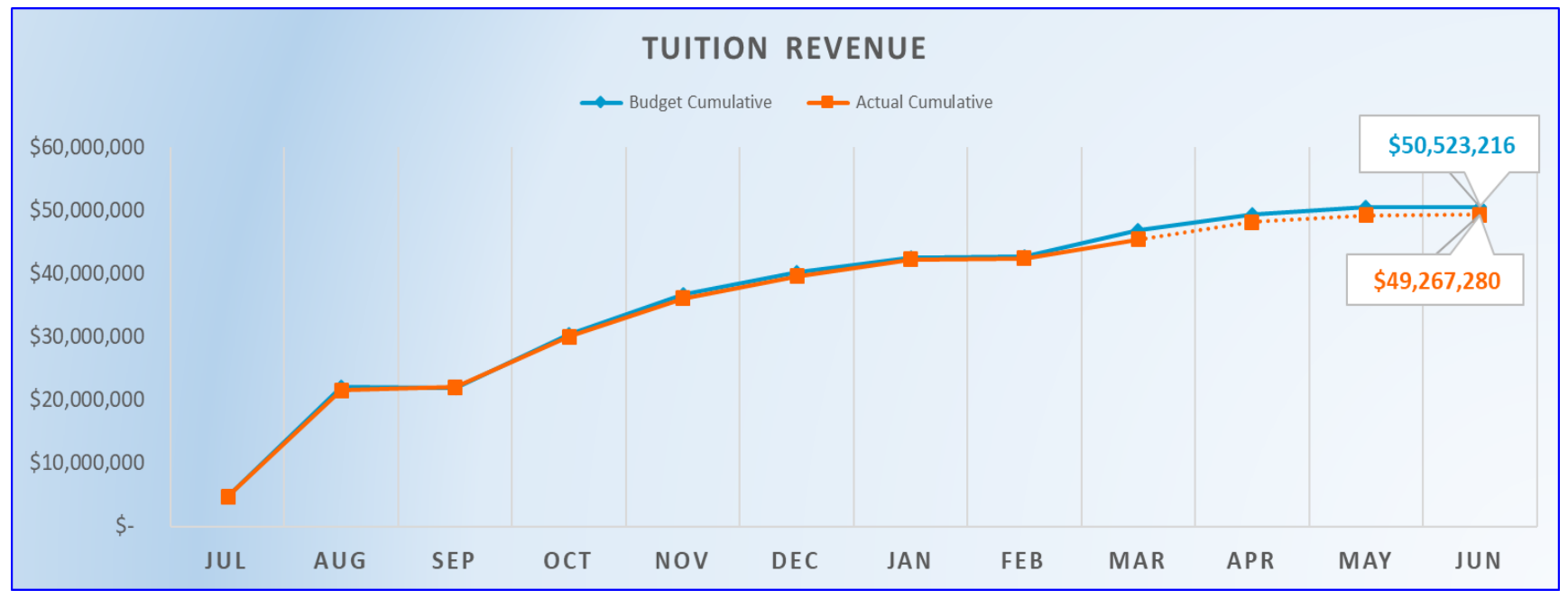

Source: SPC Board of Trustees Meeting, May 19, 2020 


\section{Exhibit 6: SPC Budget Proposal - Fund 1 Operating Fund 2020-2021}

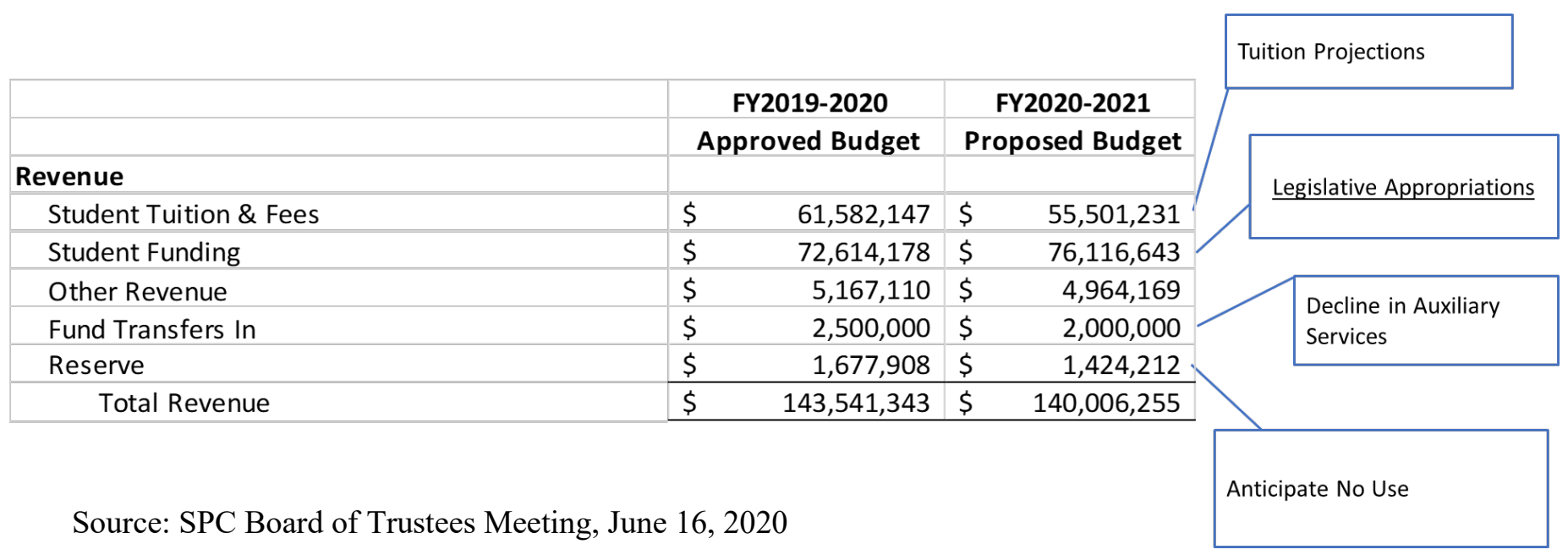

